\title{
Article \\ Differential Morphophysiological, Biochemical, and Molecular Responses of Maize Hybrids to Salinity and Alkalinity Stresses
}

\author{
Arooj Fatima ${ }^{1}$, Saddam Hussain ${ }^{1, * \mathbb{C}}$, Sadam Hussain ${ }^{1,2} \mathbb{D}^{\mathbb{B}}$, Basharat Ali ${ }^{1}$, Umair Ashraf ${ }^{3}$, Usman Zulfiqar ${ }^{1} \mathbb{D}^{\mathbb{D}}$, \\ Zubair Aslam ${ }^{1}$, Sami Asir Al-Robai ${ }^{4}$, Fatima Omari Alzahrani ${ }^{4}{ }^{\circledR}$, Christophe Hano ${ }^{5}{ }^{-}$and \\ Mohamed A. El-Esawi ${ }^{6, *(1)}$
}

Citation: Fatima, A.; Hussain, S.; Hussain, S.; Ali, B.; Ashraf, U.; Zulfiqar, U.; Aslam, Z.; Al-Robai, S.A.; Alzahrani, F.O.; Hano, C.; et al. Differential Morphophysiological, Biochemical, and Molecular Responses of Maize Hybrids to Salinity and Alkalinity Stresses. Agronomy 2021, 11, 1150. https:// doi.org/10.3390/agronomy11061150

Academic Editors: Mura Jyostna Devi and Leela Saisree Uppala

Received: 27 April 2021

Accepted: 30 May 2021

Published: 4 June 2021

Publisher's Note: MDPI stays neutral with regard to jurisdictional claims in published maps and institutional affiliations.

Copyright: (c) 2021 by the authors. Licensee MDPI, Basel, Switzerland. This article is an open access article distributed under the terms and conditions of the Creative Commons Attribution (CC BY) license (https:/ / creativecommons.org/licenses/by/ $4.0 /)$.
1 Department of Agronomy, University of Agriculture, Faisalabad 38040, Pakistan; aroojfatima0712@gmail.com (A.F.); ch.sadam423@gmail.com (S.H.); bali@uaf.edu.pk (B.A.); usmanzulfiqar2664@gmail.com (U.Z.); zubair.aslam@uaf.edu.pk (Z.A.)

2 College of Agronomy, Northwest A \& F University, Yangling 712100, China

3 Department of Botany, Division of Science and Technology, University of Education, Lahore 54770, Pakistan; umairashraf2056@gmail.com

4 Department of Biology, Faculty of Science, Albaha University, Albaha 65527, Saudi Arabia; salrobai@bu.edu.sa (S.A.A.-R.); drfatimaomari@gmail.com (F.O.A.)

5 Laboratoire de Biologie des Ligneux et des Grandes Cultures (LBLGC), INRAE USC1328, Université d'Orléans, 28000 Chartres, France; hano@univ-orleans.fr

6 Botany Department, Faculty of Science, Tanta University, Tanta 31527, Egypt

* Correspondence: shussain@uaf.edu.pk (S.H.); mohamed.elesawi@science.tanta.edu.eg (M.A.E.-E.)

Abstract: Salinity and alkalinity stresses are common in arid and semiarid climates. Both these stresses not only retard crop growth but also cause a severe reduction in yields. The present experiment was performed to investigate the morphological, physiological, biochemical, and genetic responses of two maize hybrids (FH-1231 and DK-6714) to salinity and alkalinity stresses. The treatments were comprised of salt stress $\left(\mathrm{NaCl}: \mathrm{Na}_{2} \mathrm{SO}_{4}\right.$ at a 9:1 ratio), alkaline stress $\left(\mathrm{NaHCO}_{3}: \mathrm{Na}_{2} \mathrm{CO}_{3}\right.$ at a 9:1 ratio), and an unstressed control. The results indicated that salinity and alkalinity significantly reduced shoot fresh weight by $50 \%$ and $70 \%$, root fresh weight by $38 \%$ and $50 \%$, root dry weight by $69 \%$ and $93 \%$, seedling length by $18 \%$ and $30 \%$, number of leaves by $27 \%$ and $39 \%$, and maximum leaf width by $17 \%$ and $24 \%$, respectively, across the two hybrids compared with control, indicating that alkalinity had a greater effect than salinity. Likewise, both the stresses, particularly alkalinity, significantly decreased $\mathrm{K}^{+}$ion accumulation and chlorophyll content and increased the lipid peroxidation rate, sodium $\left(\mathrm{Na}^{+}\right)$concentration, the hydrogen peroxide $\left(\mathrm{H}_{2} \mathrm{O}_{2}\right)$ level, and the activities of antioxidant enzymes, including superoxide dismutase (SOD), catalase (CAT), peroxidase (POD), and ascorbate peroxidase (APX). Salinity and alkalinity stresses also induced the expression levels of antioxidant genes $(S O D, C A T, P O D, A P X)$; however, salinity showed less effect than alkalinity stress. Similarly, hybrid DK-6714 performed comparatively better than FH-1231 with regard to seedling growth, antioxidant activities, and biochemical attributes under stress conditions. Thus, DK-6714 is recommended as a suitable hybrid for soils affected with salt-alkalization.

Keywords: alkalinity; antioxidants; gene expression; ionic balance; maize hybrids; stress tolerance

\section{Introduction}

The occurrence of salinity and alkalinity stress is a major issue in arid and semiarid areas, where rainfall is insufficient for better plant growth [1]. These stresses can adversely affect plant growth and production [2]. Maize (Zea mays L.) is known as the queen of cereals and is grown in more than 116 countries due to its high yield potential and versatility [3]. It ranks third in the world after wheat and rice in terms of cultivation area, while in Pakistan, it is the fourth major crop after wheat, cotton, and rice [4]. The maize crop is grown between $50^{0}$ north latitude to $40^{0}$ south latitude, where biotic and abiotic stresses are commonly found [5]. Various abiotic stresses (such as waterlogging, drought, salinity, high and low 
temperatures, and nutrient stress) negatively affect maize yield [6]. In particular, maize is a quite sensitive crop to salt stress [7].

Salinity and alkalinity are two different types of stresses that restrict plant growth [8]. Salinity is caused by neutral salts such as $\mathrm{NaCl}$ and $\mathrm{Na}_{2} \mathrm{SO}_{4}$, while alkalinity is caused by alkaline salts such as $\mathrm{NaHCO}_{3}$ and $\mathrm{Na}_{2} \mathrm{CO}_{3}$ [9]. It is estimated that about 932 mha of land worldwide is affected by salt-alkalization $[10,11]$. In Pakistan, the majority of the soils contain low organic matter and are alkaline in nature, with $\mathrm{pH} \geq 8$, due to a high concentration of calcium carbonate, and the salt-affected area in Pakistan is 6.30 mha $[12,13]$.

Both salinity and alkalinity stresses are the major limiting factors for plant growth and development [2]. The most common morphological symptom of salinity stress on plants is decreased growth, which is the result of many physiological responses $[14,15]$. Soil alkalization mostly occurs simultaneously with soil salinization [16,17]. Alkalinity has similar effects to soil salinity and has an additional effect due to high $\mathrm{pH}$ [18,19]. A high concentration of alkaline salts reduces growth and biomass accumulation in plants [20]. Under neutral and alkaline salt stress, chlorophyll content and the relative growth rate of root and shoot were decreased, but such decrease was greater under alkaline salt stress [21].

Salinity and alkalinity severely interfere with the ion uptake mechanism. The excessive accumulation of $\mathrm{Na}^{+}$ions under salt stress reduces the uptake of $\mathrm{K}^{+}$ions [22,23]. Ionic toxicity disturbs the osmotic balance and leads to reduced plant growth [24]. Ion toxicity reduces growth and causes premature leaf senescence that leads to a reduction in photosynthetic pigments because leaves are an important photosynthetic area that converts light energy to potential energy through green pigments [25-27]. Under stress conditions, lipid peroxidation is also the result of specific ion toxicity or excessive accumulation of $\mathrm{Na}^{+}$ ions [28]. The malondialdehyde (MDA) content in Populus cathayana was increased with an increase in alkalinity stress, which indicates that a high level of soil alkalinity severely damages the membranes [23].

Both of these stresses trigger the production of reactive oxygen species (ROS) in plants [29]. Reactive oxygen species, such as singlet oxygen, superoxide radical, hydroxyl ion and hydrogen peroxide $\left(\mathrm{H}_{2} \mathrm{O}_{2}\right)$, are produced in plants even under normal conditions during photosynthesis, respiration, and photorespiration, but plant cells maintain a balance between ROS and antioxidants [29-31]. However, an increase in synthesis and accumulation of ROS causes membrane denaturation by reacting with proteins, DNA, lipids, and other macromolecules [32]. Under the influence of saline and alkaline salts, the over-accumulation of ROS enhances the activity of antioxidant enzymes such as SOD, CAT, POD, and APX that are involved in the mitigation of ROS [33,34]. Although a number of studies have reported that neutral and alkaline salt stresses cause changes in the growth, physiology, and oxidative metabolism of crops, the effects of salt-alkalization on the growth and oxidative metabolism of maize are poorly understood. Therefore, the present study was conducted to evaluate the effects of salt-alkalization on the morphology, growth, chlorophyll content, reactive oxygen species, and antioxidant defense system of two maize hybrids.

\section{Materials and Methods}

\subsection{Plant Material and Experimental Design}

Two maize hybrids, FH-1231 and DK-6714, were used for this experiment. In a preliminary experiment on germination and seedling growth, DK-6714 appeared moderately tolerant, while FH-1231 was sensitive to salt stress (data not shown). Both of these hybrids are commonly grown by the local maize farmers of Punjab-Pakistan. The seeds of FH-1231 and DK-6714 were collected from Ayub Agricultural Research Institute, Faisalabad, and Monsanto, Pakistan (Pvt.), respectively. The recommended dose of fertilizers (250:140:90 $\mathrm{mg} /$ pot N:P:K) was applied as a basal dose. Urea was used as a nitrogen source, while single super phosphate (SSP) and sulfate of potash (SOP) were used as the source of phosphorus and potassium, respectively. The experiment was carried out in the greenhouse of the Department of Agronomy, University of Agriculture Faisalabad. The experiment was 
arranged in a completely randomized design under the factorial arrangement, with four replicates. The experiment contained 24 pots. In each pot, 15 seeds were sown at equal distances, and 5 seedlings were thinned out after emergence. The treatments included salt stress $\left(\mathrm{NaCl}: \mathrm{Na}_{2} \mathrm{SO}_{4}\right.$ with a ratio of 9:1), alkaline stress $\left(\mathrm{NaHCO}_{3}: \mathrm{Na}_{2} \mathrm{CO}_{3}\right.$ with a ratio of 9:1), and a no-stress control. For saline and alkaline stresses, electric conductivity (EC) was maintained at $8 \mathrm{dSm}^{-1}$, while the $\mathrm{pH}$ values of neutral and alkaline salts were 7.8 and 9.4, respectively.

\subsection{Data Recorded}

\subsubsection{Morphological Growth}

After 20 days of the treatment application, the plants were harvested. The shoot and root lengths were measured by using a meter rod. After the dissection of roots and shoots, their fresh and dry weights were measured by using an electric balance. To measure the dry weight of roots and shoots, the samples were sun-dried for three days and then oven-dried at $75^{\circ} \mathrm{C}$ until constant weight.

\subsubsection{Photosynthetic Pigments}

The chlorophyll contents in maize hybrids were determined according to the method of $\mathrm{Xu}$ et al. [35]. Briefly, fresh leaves were chopped into small pieces and added to $5 \mathrm{~mL}$ of $80 \%$ acetone. This solution was then filtered and centrifuged at $14,000 \mathrm{rpm}$ and $4{ }^{\circ} \mathrm{C}$ for $15 \mathrm{~min}$. The absorbance of the sample was measured at wavelengths of 665,649 , and $470 \mathrm{~nm}$ for chlorophyll a, chlorophyll b, and carotenoids, respectively.

\subsubsection{Inorganic Ion}

The $\mathrm{Na}^{+}$and $\mathrm{K}^{+}$ion concentrations were measured according to the method of Williams and Twine [36]. The dried plant material was ground and treated with $2 \mathrm{~mL}$ of $80 \%$ perchloric acid and $10 \mathrm{~mL}$ of concentrated sulphuric acid for $12 \mathrm{~h}$. The digested material was then diluted to a volume of $100 \mathrm{~mL}$ with distilled water, and the concentrations of $\mathrm{Na}^{+}$and $\mathrm{K}^{+}$were measured by a flame photometer.

\subsubsection{Lipid Peroxidation and $\mathrm{H}_{2} \mathrm{O}_{2}$ Content}

The $\mathrm{H}_{2} \mathrm{O}_{2}$ content was determined according to the method of Velikova et al. [37], while the lipid peroxidation rate was determined as the MDA content using the method of Heath and Packer [38]. A fresh leaf sample of $250 \mathrm{mg}$ was frozen in liquid nitrogen, and then leaves were ground in trichloroacetic acid (TCA, $3 \mathrm{~mL}$ ) and centrifuged at 13,000 $\times g$ for $7 \mathrm{~min}$ at $4{ }^{\circ} \mathrm{C}$. Then, $2 \mathrm{~mL}$ of supernatant was mixed with $0.67 \% \mathrm{TCA}(2 \mathrm{~mL})$ and heated at $100{ }^{\circ} \mathrm{C}$ for $30 \mathrm{~min}$. Afterward, the mixture was centrifuged again at $12,000 \times g$ for $10 \mathrm{~min}$, and the absorbance was recorded at 532 and $600 \mathrm{~nm}$ wavelengths. The blank sample of $0.025 \%$ thiobarbituric acid in $10 \%$ TCA was also run. The content of MDA was computed using the given formula and is showed in $\mu \mathrm{mol} \mathrm{g}^{-1} \mathrm{FW}$ :

$$
\mathrm{MDA}=(\mathrm{A} 532-\mathrm{A} 600) / \varepsilon
$$

where, $\varepsilon$ is the extinction coefficient.

\subsubsection{Antioxidant Enzymes Activities}

The activities of CAT and POD in maize leaves were determined according to the method of Chance and Maehly [39]. For CAT activity, $0.3 \mathrm{~mL}$ of enzyme solution, $0.3 \mathrm{~mL}$ of phosphate buffer (pH 7.8), and $4.5 \mathrm{~mL}$ of $100 \mathrm{mM} \mathrm{H}_{2} \mathrm{O}_{2}$ were added to a $10 \mathrm{~mL}$ test tube, and absorbance was measured at $240 \mathrm{~nm}$ at one-minute intervals for $4 \mathrm{~min}$. To determine POD activity, a reaction mixture containing $50 \mathrm{mM}$ of phosphate buffer (pH 7.0), $10 \mathrm{mM}$ guaiacol, and $5 \mathrm{mM}$ of $\mathrm{H}_{2} \mathrm{O}_{2}$ was prepared. The mixture was preheated at $25^{\circ} \mathrm{C}$ in a water bath, and then $0.3 \mathrm{~mL}$ enzyme solution and $2.8 \mathrm{~mL}$ of reaction solution were added to a $10 \mathrm{~mL}$ centrifuge tube and mixed thoroughly. The absorbance of the mixture was measured at $470 \mathrm{~nm}$ at one-minute intervals, and the measurement continued for $4 \mathrm{~min}$. SOD activity 
was measured according to the method of Dhindsa et al. [40]. Samples of fresh leaves $(0.2 \mathrm{~g})$ were homogenized in $2 \mathrm{~mL}$ of ice-cold, $0.1 \mathrm{M}$ phosphate buffer of $7.8 \mathrm{pH}, 0.1 \mathrm{mM}$ EDTA, and $0.1 \%$ polyvinylpyrrolidone and centrifuged at $12,000 \mathrm{rpm}$ and $4{ }^{\circ} \mathrm{C}$ for $15 \mathrm{~min}$. In a $10 \mathrm{~mL}$ test tube, $0.2 \mathrm{~mL}$ extract solution, $1.6 \mathrm{~mL}$ phosphate buffer, $0.3 \mathrm{~mL}$ of $130 \mathrm{mmol} / \mathrm{L}$ Met buffer, $0.3 \mathrm{~mL}$ of $750 \mu \mathrm{mol} / \mathrm{L}$ NBT buffer, $0.3 \mathrm{~mL}$ of $100 \mu \mathrm{mol} / \mathrm{L}$ EDTA-Na 2 buffer, and $0.3 \mathrm{~mL}$ of $20 \mu \mathrm{mol} / \mathrm{L}$ lactoflavin were mixed, and then the absorbance was recorded. APX activity was determined according to the method of Nakano and Asada [41]. The reaction mixture was prepared by mixing $50 \mathrm{mM}$ phosphate buffer ( $\mathrm{pH} 7.0), 0.25 \mathrm{mM}$ ascorbic acid, $1 \mathrm{mM} \mathrm{H}_{2} \mathrm{O}_{2}$, and $0.1 \mathrm{mM}$ EDTA. In a $10 \mathrm{~mL}$ centrifuged tube, $2.8 \mathrm{~mL}$ reaction solution and $0.2 \mathrm{~mL}$ enzyme solution were mixed immediately, and the absorbance was measured at $290 \mathrm{~nm}$ at one-minute intervals; the measurement continued for $4 \mathrm{~min}$.

\subsubsection{RNA Isolation, cDNA Synthesis, and Transcriptional Analysis}

Quantitative real-time PCR (qRT-PCR) analysis was carried out to assess the expression levels of the genes encoding antioxidant enzymes (catalase (CAT), superoxide dismutase (SOD), peroxidase $(P O D)$, and ascorbate peroxidase $(A P X))$ in 20-day-old maize seedlings of the two hybrids (DK-6714 and FH-1231). Total RNA was extracted in liquid nitrogen from the fresh plant tissues, and cDNA was obtained using the RNeasy Plant Mini Kit and the Reverse Transcription Kit (Qiagen, Hilden, Germany), respectively. All reactions were done in triplicate in a final volume of $25 \mu \mathrm{L}$, following the manufacturer's protocol of the QuantiTect SYBR Green PCR Kit (Qiagen, Hilden, Germany). PCR amplification conditions were $95{ }^{\circ} \mathrm{C}$ for $10 \mathrm{~min} ; 40$ cycles of $95^{\circ} \mathrm{C}$ for $20 \mathrm{~s}, 60^{\circ} \mathrm{C}$ for $30 \mathrm{~s}, 72{ }^{\circ} \mathrm{C}$ for $2 \mathrm{~min}$, and $72{ }^{\circ} \mathrm{C}$ for $4 \mathrm{~min}$. A melt-curve analysis was assayed to verify the amplification specificity. Gene specific-primers for SOD and APX [42,43] as well as for CAT and POD [44] were obtained from the previous studies (Table 1). The Actin2 gene was used as an internal reference [44], and the levels of the relative gene expression were determined by the $2^{-\Delta \Delta C t}$ method [45].

Table 1. Primer sequences for qRT-PCR amplification of antioxidant genes.

\begin{tabular}{ccccc}
\hline Genes & $\begin{array}{c}\text { Gene ID } \\
\text { (Accession Number) }\end{array}$ & Primer Sequences (5'-3') & References \\
\hline SOD (superoxide dismutase 4) & NM_001112234 & $\begin{array}{c}\text { F: TGGAGCACCAGAAGATGA } \\
\text { R: CTCGTGTCC ACCCTTCC }\end{array}$ & $\begin{array}{c}\text { Vwioko et al. [42]; } \\
\text { Neta et al. [43] }\end{array}$ \\
\hline APX (ascorbate peroxidase 2) & NM_001112030 & $\begin{array}{c}\text { F: TGAGCGACCAGGACATTG } \\
\text { R: GAGGGCTTTGTCACTTGGT }\end{array}$ & $\begin{array}{c}\text { Vwioko et al. [42]; } \\
\text { Neta et al. [43] }\end{array}$ \\
\hline CAT (catalase isomer 3) & NM_001152957 & $\begin{array}{c}\text { F: AATCGCCTCACGAATCGGTCCT } \\
\text { R: CGCACCACAACAACCACTACGA }\end{array}$ & Huang et al. [44] \\
\hline POD (peroxidase 39 isoform X1) & NM_001112570 & F: TCGGCGTCATCGTCAGTGCT & Huang et al. [44] \\
\hline Actin2 & EU958048 & $\begin{array}{c}\text { F: TGAAACCTTCGAATGCCCAG } \\
\text { R: GATTGGAACCGTGTGGCTCA }\end{array}$ & Huang et al. [44] \\
\hline
\end{tabular}

\subsection{Statistical Analysis}

Data collected was analyzed using a two-factor factorial experiment under a completely randomized design (CRD), and the comparison among treatment means was done using a least significant difference (LSD) test at a probability level of $5 \%$.

\section{Results}

\subsection{Seedling Fresh and Dry Weights}

Both salinity and alkalinity treatments significantly reduced seedling fresh and dry weights (Figure 1). Salinity stress reduced the shoot fresh weight of DK-6714 and FH-1231 by $49 \%$ and $50 \%$, root fresh weight by $31 \%$ and $46 \%$, shoot dry weight by $64 \%$ and $72 \%$, and root dry weight by $68 \%$ and $70 \%$, respectively, compared with control. Exposure to 
alkalinity stress reduced the shoot fresh weight of DK- 6714 and FH- 1231 by $65 \%$ and $75 \%$, root fresh weight by $49 \%$ and $50 \%$, shoot dry weight by $81 \%$ and $86 \%$, and root dry weight by $93 \%$ and $93 \%$, respectively, over control. For all traits, the negative effects of alkalinity stress were more severe than salinity stress. Under stress conditions, DK-6714 performed better than FH-1231 and recorded less reduction in growth and biomass (Figure 1).

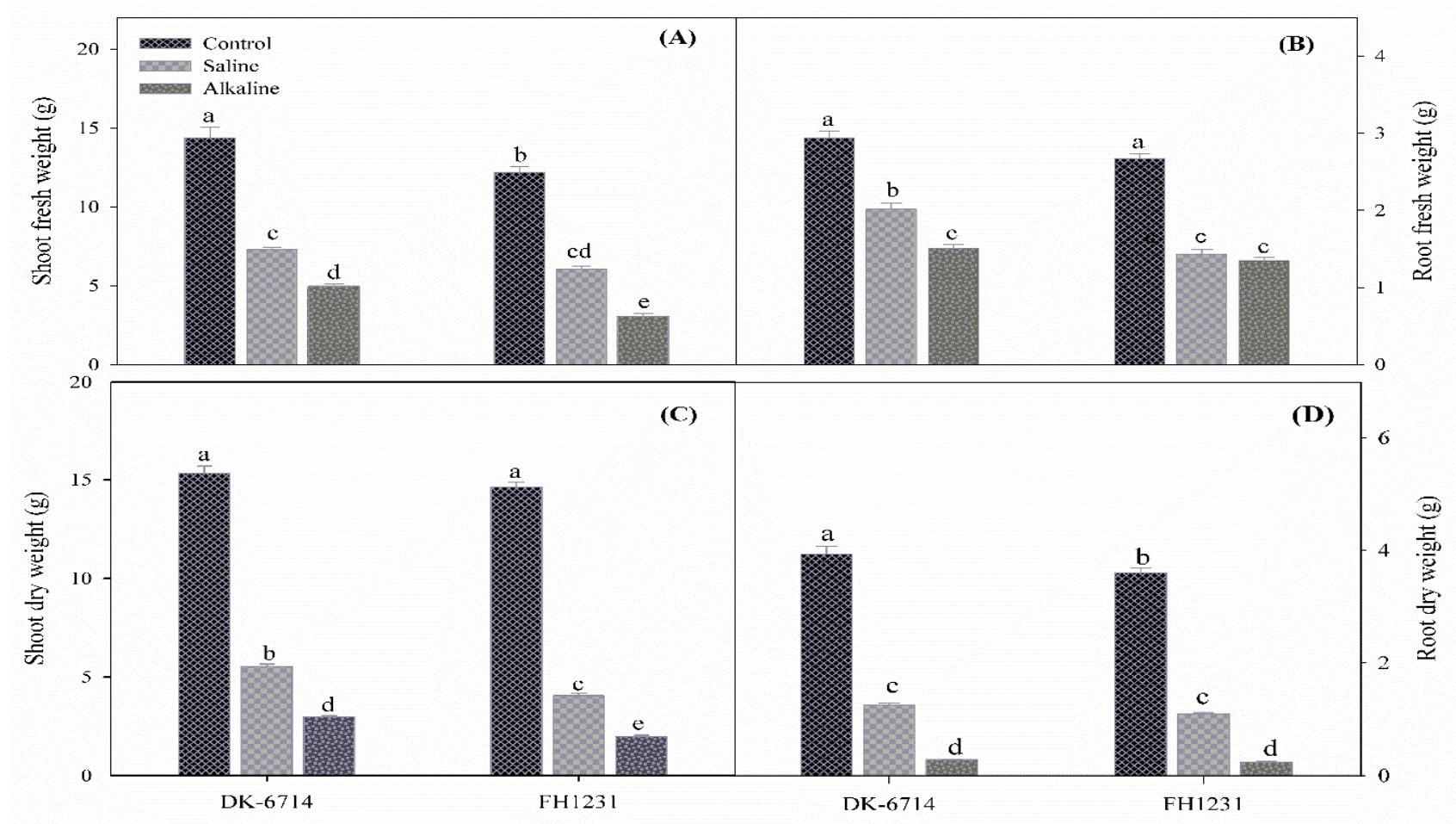

Figure 1. Effect of salinity and alkalinity stress on (A) shoot fresh weight, (B) root fresh weight, (C) shoot dry weight, and (D) root dry weight of 20-day-old maize hybrids (DK-6714 and FH-1231). The bars represent the standard error ( \pm SE) of the four replicates. Similar small letters above bars represent nonsignificant (ns) differences among treatments $(p \leq 0.05)$.

\subsection{Seedling Length and Number of Leaves}

Seedling length, number of leaves per seedling, and maximum leaf width differed significantly among salt treatments and maize hybrids (Figure 2). Salinity stress reduced the shoot length by $19 \%$ and $21 \%$, root length by $15 \%$ and $16 \%$, number of leaves by $27 \%$ and $27 \%$, and maximum leaf width by $10 \%$ and $25 \%$ in DK-6714 and FH-1231, respectively, compared with control. Exposure of alkalinity stress reduced the shoot length by $29 \%$ and $32 \%$, root length by $29 \%$ and $32 \%$, number of leaves by $37 \%$ and $40 \%$, and maximum leaf width by $14 \%$ and $33 \%$ in DK-6714 and FH-1231, respectively, over control, indicating that the negative effects of alkalinity stress were more severe than salinity stress. Under saline and alkaline stress conditions, DK-6714 showed less reduction in the above parameters compared with FH-1231 (Figure 2). 


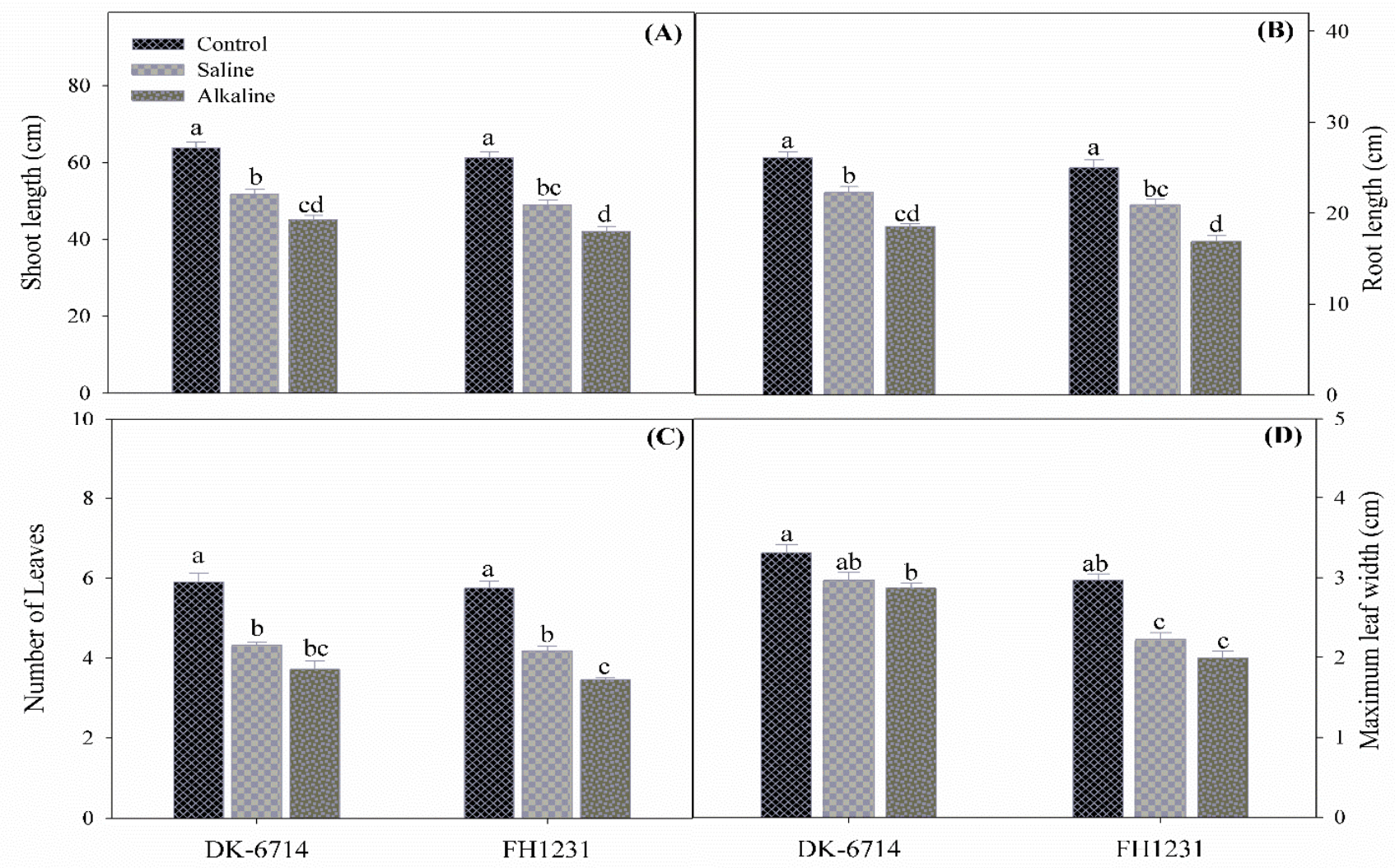

Figure 2. Effect of salinity and alkalinity stress on (A) shoot length, (B) root length, (C) number of leaves per seedling, and (D) maximum leaf width of 20-day-old maize seedlings of two hybrids (DK-6714 and FH-1231). The bars represent the standard error (SE) of the four replicates. Similar small letters above bars represent nonsignificant (ns) differences among treatments $(p \leq 0.05)$.

\subsection{Chlorophyll Content and Carotenoid Content}

Salt-alkalization and maize hybrids recorded significant differences in chlorophyll and carotenoid contents in maize leaves (Figure 3). Under salinity stress, Chl a, Chl b, total chlorophyll, and carotenoid contents in both hybrids were reduced by $6-33 \%$ compared with the control. Exposure of alkalinity stress also reduced the $\mathrm{Chl}$ a content by $17 \%$ and $19 \%$, Chl b content by $11 \%$ and $18 \%$, total chlorophyll content by $12 \%$ and $18 \%$, and carotenoid content by $48 \%$ and $53 \%$ in DK-6714 and FH-1231, respectively, as compared with control treatments. The negative effects of alkalinity stress were more severe than salinity stress. Compared with FH-1231, DK-6714 recorded less reduction in the accumulation of photosynthetic pigments under stress conditions (Figure 3). 


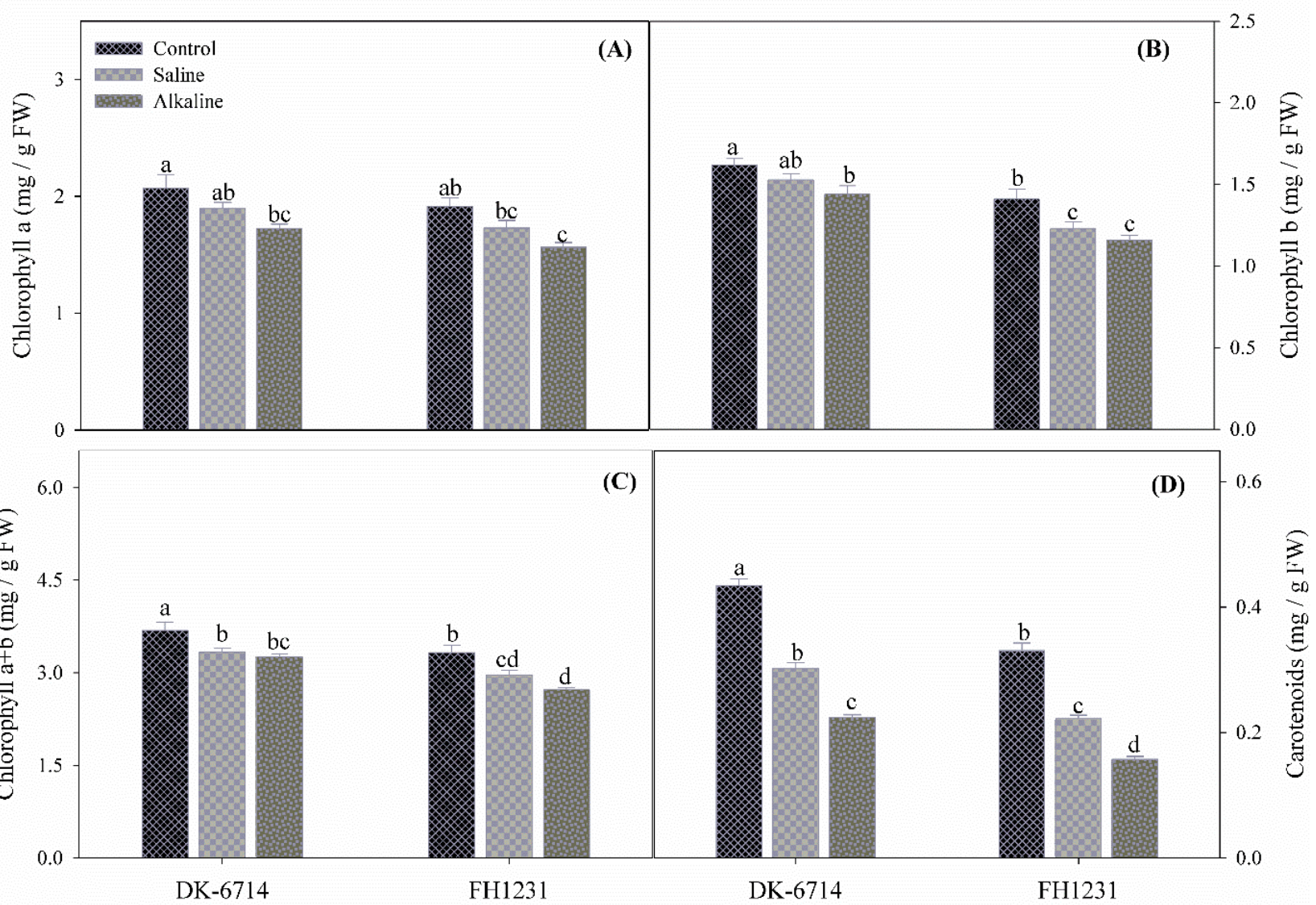

Figure 3. Effect of salinity and alkalinity stress on (A) chlorophyll a, (B) chlorophyll b, (C) chlorophyll a $+b$, and (D) carotenoid content of 20-day-old maize seedlings of two hybrids (DK-6714 and FH-1231). The bars represent the standard error (SE) of the four replicates. Similar small letters above bars represent nonsignificant (ns) differences among treatments $(p \leq 0.05)$.

\subsection{Ions Accumulation}

Salt treatments and maize hybrids significantly affected ion accumulation (Figure 4). Under salinity stress, $\mathrm{K}^{+}$ion accumulation in both hybrids was significantly decreased (8-25\%) compared with control. However, salinity stress increased the $\mathrm{Na}^{+}$ions in DK-6714 and $\mathrm{FH}-1231$ by $8 \%$ and $12 \%$, respectively, over control. Exposure to alkalinity stress reduced leaf $\mathrm{K}^{+}$concentration by $20 \%$ and $25 \%$ while increasing leaf $\mathrm{Na}^{+}$concentrations by $23 \%$ and $25 \%$ in DK-6714 and FH-1231, respectively, compared with control. The hybrid DK-6714 was comparatively better than FH-1231 with regard to the maintenance of ionic balance under stress conditions (Figure 4). 


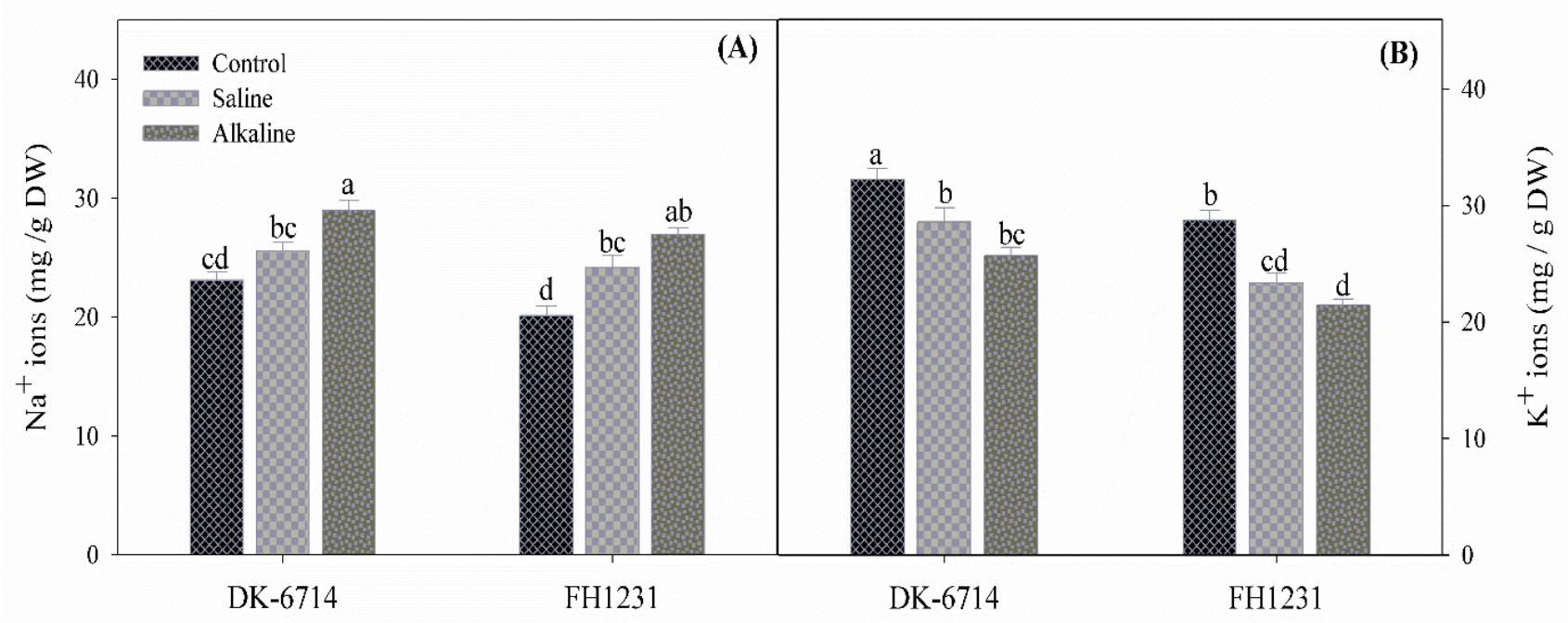

Figure 4. Effect of salinity and alkalinity stress on (A) Na+ ions and (B) K+ ions in 20-day-old maize seedlings of two hybrids (DK-6714 and FH-1231). The bars represent the standard error (SE) of the four replicates. Similar small letters above bars represent nonsignificant (ns) differences among treatments $(p \leq 0.05)$.

\subsection{Hydrogen Peroxide and Lipid Peroxidation}

Compared with the control, salinity stress increased the $\mathrm{H}_{2} \mathrm{O}_{2}$ content in DK-6714 and FH-1231 by $18 \%$ and $19 \%$ and the MDA content by $36 \%$ and $41 \%$, respectively (Figure 5). Similarly, alkalinity stress increased the $\mathrm{H}_{2} \mathrm{O}_{2}$ content by $36 \%$ and $76 \%$ and the MDA content by $65 \%$ and $72 \%$ in DK-6714 and $\mathrm{FH}-1231$, respectively, compared to control. FH-1231 recorded higher $\mathrm{H}_{2} \mathrm{O}_{2}$ and MDA content than DK-6714 under both salinity and alkalinity stresses (Figure 5).

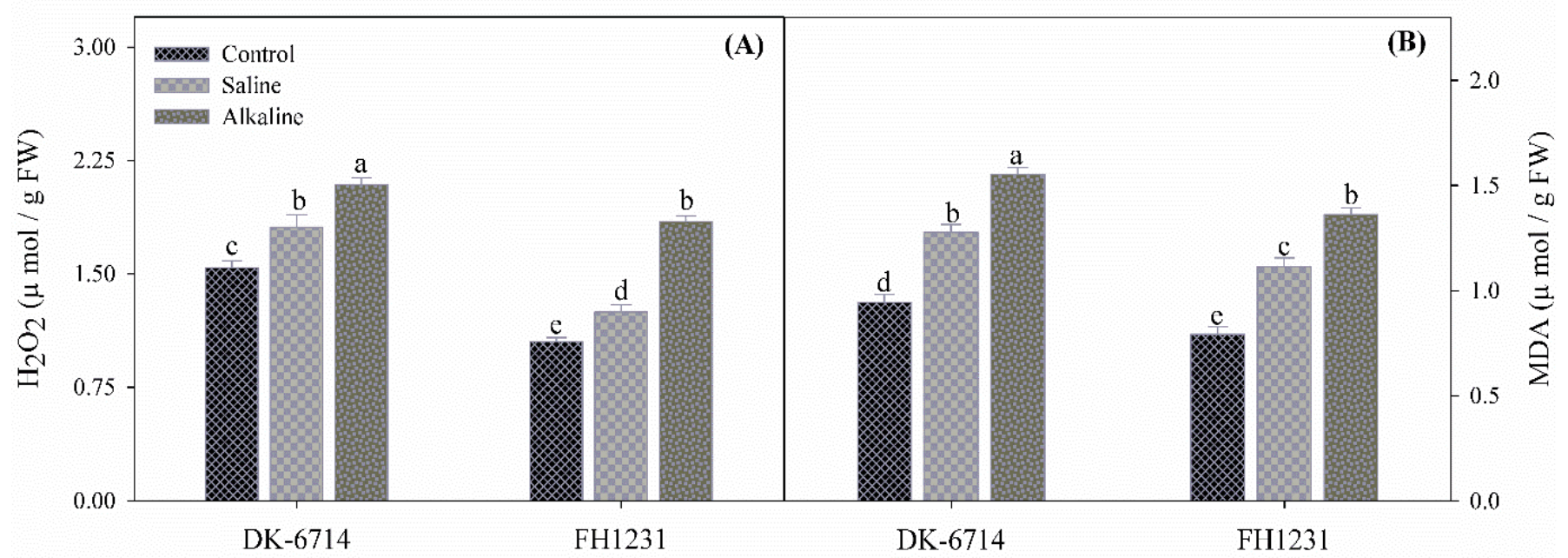

Figure 5. Effect of salinity and alkalinity stress on (A) hydrogen peroxide $\left(\mathrm{H}_{2} \mathrm{O}_{2}\right)$ and $(\mathbf{B})$ malondialdehyde (MDA) content in 20-day-old maize seedlings of two hybrids (DK-6714 and FH-1231). The bars represent the standard error (SE) of the four replicates. Similar small letters above bars represent nonsignificant (ns) differences among treatments $(p \leq 0.05)$.

\subsection{Antioxidant Enzymatic Activity}

Salt treatments and hybrids significantly affected the activities of antioxidant enzymes (Figure 6). Salinity stress enhanced SOD activity by $25 \%$ and $21 \%$, CAT activity by $57 \%$ and $54 \%$, POD activity by $19 \%$ and $16 \%$, and APX activity by $49 \%$ and $47 \%$ in DK-6714 and FH-1231, respectively, compared with control. In DK-6714 and FH-1231, alkalinity stress increased SOD activity by $43 \%$ and $40 \%$, CAT activity by $81 \%$ and $72 \%$, POD activity by $30 \%$ 
and $29 \%$, and APX activity by $82 \%$ and $78 \%$, respectively, compared with control. Under both saline and alkaline stress conditions, the hybrid DK-6714 showed higher activities of antioxidant enzymes compared with the FH-1231 hybrid (Figure 6).
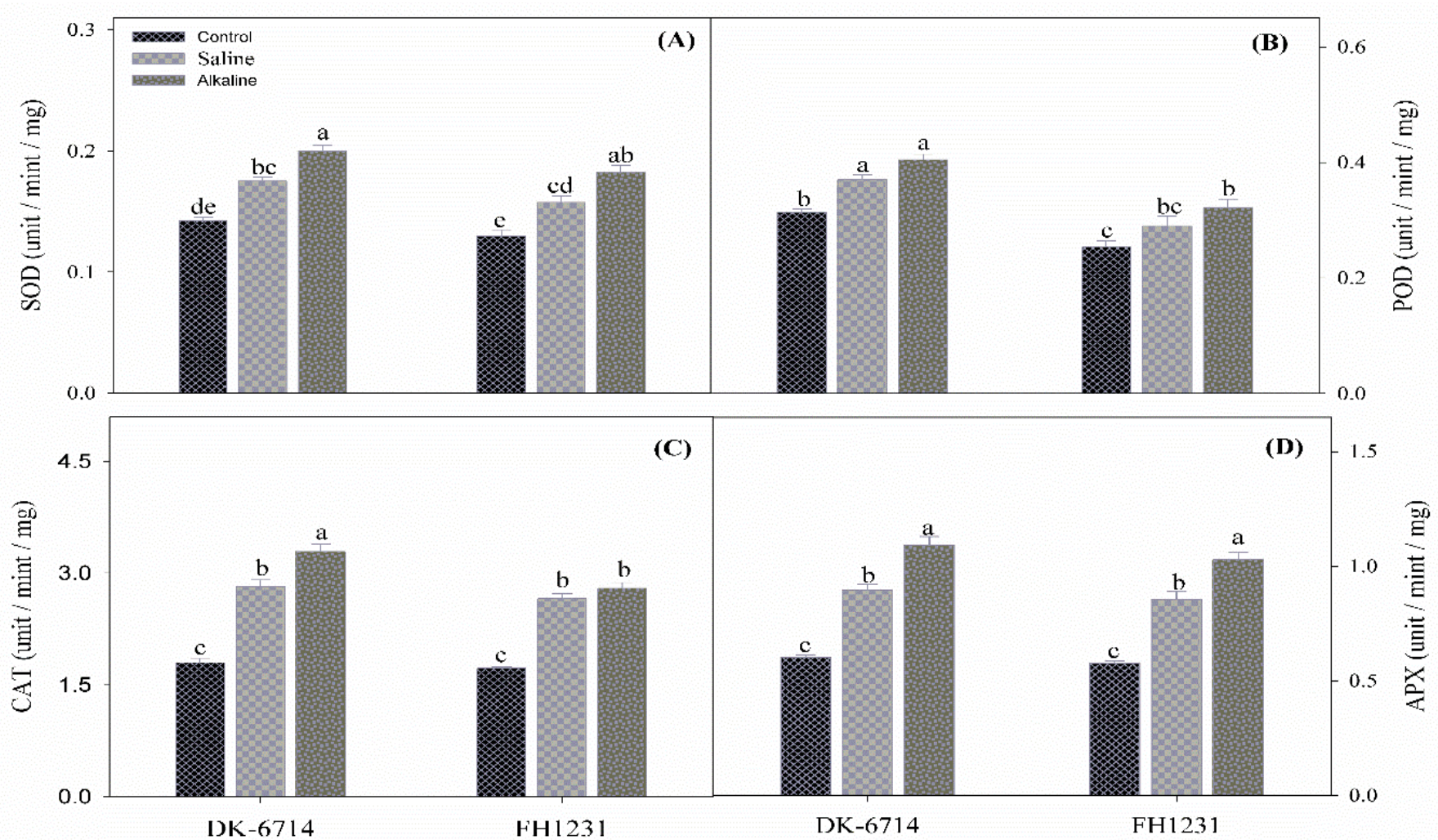

Figure 6. Effect of salinity and alkalinity stress on (A) superoxide dismutase (SOD), (B) peroxidases (POD), (C) catalase (CAT), and (D) ascorbate peroxidase (APX) activities in 20-day-old maize seedlings of two hybrids (DK-6714 and FH-1231). The bars represent the standard error (SE) of the four replicates. Similar small letters above bars represent nonsignificant (ns) differences among treatments $(p \leq 0.05)$.

\subsection{Gene Expression Analysis}

Both salinity and alkalinity stress significantly induced the expression levels of antioxidant genes (Figure 7). Salinity stress induced the expression levels of the CAT gene by $85 \%$ and $43 \%$, the SOD gene by $65 \%$ and $38 \%$, the $P O D$ gene by $74 \%$ and $65 \%$, and the APX gene by $43 \%$ and $27 \%$ in DK-6714 and FH-1231, respectively, compared to control. On the other hand, alkalinity stress enhanced the expression levels of the CAT gene by $94 \%$ and $67 \%$, the SOD gene by $88 \%$ and $52 \%$, the $P O D$ gene by $97 \%$ and $73 \%$, and the $A P X$ gene by $61 \%$ and $72 \%$ in DK-6714 and FH-1231, respectively, compared to control. Under saline and alkaline stress conditions, the hybrid DK-6714 showed a higher expression of antioxidant genes than FH-1231 (Figure 7). 

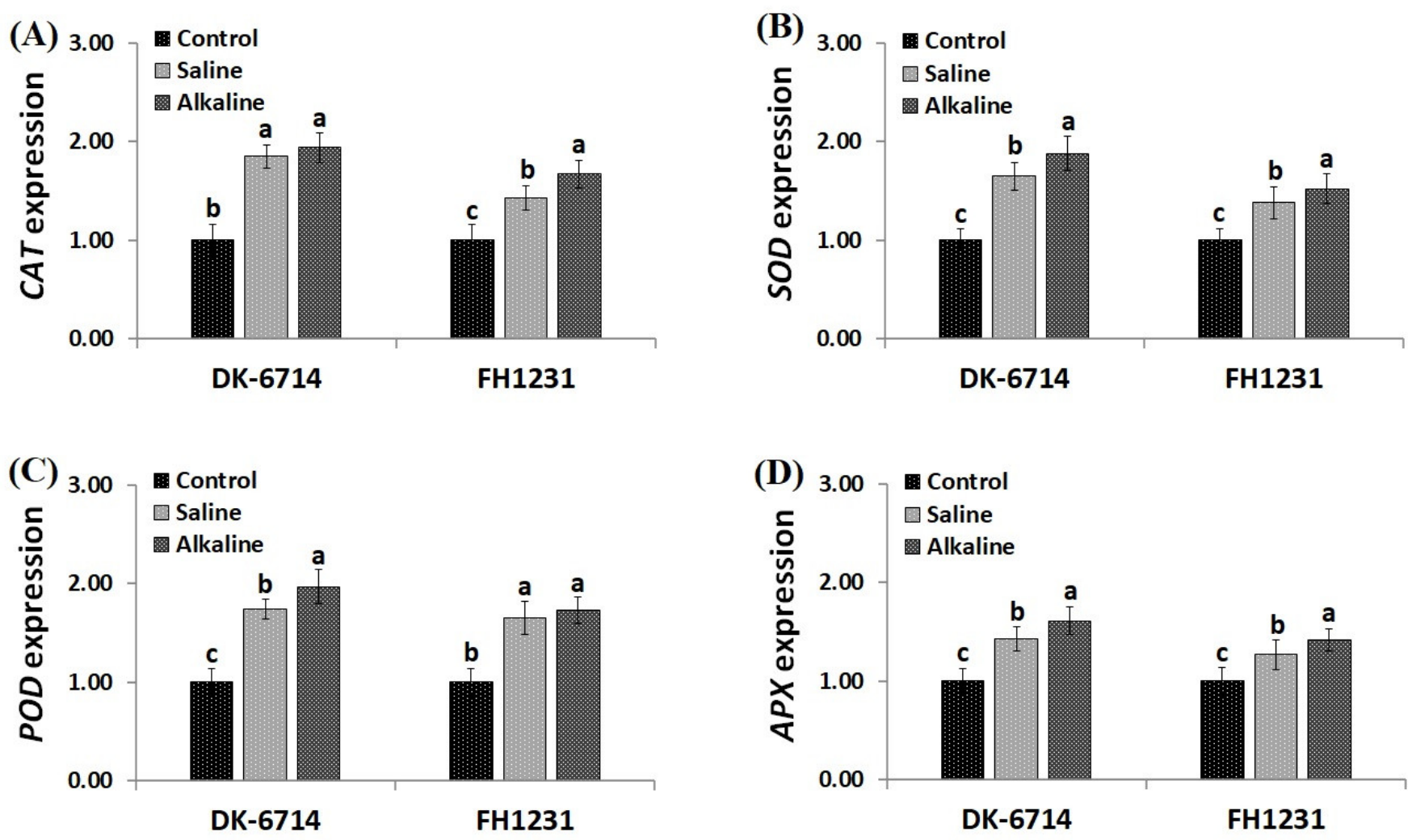

Figure 7. Effect of salinity and alkalinity stress on the expression levels of (A) the catalase (CAT) gene, (B) the superoxide dismutase $(S O D)$ gene, $(\mathbf{C})$ the peroxidase $(P O D)$ gene, and (D) the ascorbate peroxidase $(A P X)$ gene in 20-day-old maize seedlings of two hybrids (DK-6714 and FH-1231). The bars represent the standard error (SE) of three replicates. Similar small letters above bars represent nonsignificant (ns) differences among treatments $(p \leq 0.05)$.

\section{Discussion}

Maize crops are sensitive to high concentrations of neutral and alkaline salts. Increasing crop yields in saline- and alkaline-affected areas is an important task because the increasing amount of salt-alkali soils has reduced the productivity of agricultural land and brought about an ecological crisis to mankind [20]. The present study examined the morphological, physiological, biochemical, and molecular responses of two maize hybrids to salinity and alkalinity stresses and demonstrated the comparative effects of both stresses on morphological processes and the oxidative metabolism of maize hybrids.

In this study, both salinity and alkalinity caused a marked reduction in fresh and dry weights of root and shoot, leaf area, and number of leaves in maize. Although both stresses reduced plant growth and biomass, the impact of alkalinity stress was more severe than salinity stress (Figures 1 and 2). The reduced biomass and growth under saline salts might be due to specific ion toxicity and osmotic imbalance; however, under alkaline salts, the high $\mathrm{pH}$ of the soil might also have affected plant growth. High soil $\mathrm{pH}$ damages the root cells of rice and inhibits seedling growth, which sometimes led to plant wilting and even death [46-48]. The high concentration of saline and alkaline salts in the rhizosphere inhibits the elongation process of plants by accumulating high $\mathrm{Na}^{+}$ ions and low $\mathrm{K}^{+}$ions into the cells. Potassium ions play an important role in cell osmotic pressure. Due to the greater accumulation of $\mathrm{Na}^{+}$ions and the loss of cell expansion pressure, cells become rigid and cannot reach their maximum size $[46,47]$. Abd-Elgawad et al. [49] observed that under salinity, maize roots accumulated more $\mathrm{Na}^{+}$ions and showed more reduction in plant biomass. Under the influence of alkalinity, insufficient nutrient supply caused by high soil $\mathrm{pH}$ can inhibit plant growth [50,51]. The present study reveals that salt-alkalization reduced the accumulation of photosynthetic pigments in maize leaves 
(Figure 3). Chlorophyll contents ( $\mathrm{Chl}$ a and b) play a special role in photosynthesis, and a decline in photosynthetic pigments reduces the photosynthesis rate and food supply for plant growth [52,53].

In this study, the chlorophyll contents of both hybrids were decreased under salinity and alkalinity stresses, and such reductions were more severe under alkalinity stress. Several authors have reported that salinity and alkalinity stresses increase the activity of chlorophyll-degrading enzymes, thereby reducing total chlorophyll content $[27,54,55]$. Alkalinity reduces the uptake of $\mathrm{Mg}^{2+}$ ions, which are the building block of chlorophyll and the central atom of the chlorophyll molecule. A decrease in $\mathrm{Mg}^{2+}$ concentration under alkaline stress can lead to the degradation of green pigments [18]. Moreover, salt-induced oxidative stress affects the structure of the chloroplast and causes the degradation of chlorophyll in plants. This is due to the increase of chlorophyllase enzyme activity, which leads to a decrease in the photosynthetic rate under alkaline stress [56-58].

For normal function of the enzymatic processes in cells, high $\mathrm{K}^{+}$ions and low $\mathrm{Na}^{+}$ ions in the cytoplasm are essential. In the present study, both salinity and alkalinity stresses increased $\mathrm{Na}^{+}$while decreasing the $\mathrm{K}^{+}$concentration in maize leaves; however, such effects were prominent under alkalinity stress (Figure 4). The accumulation of $\mathrm{Na}^{+}$in cells is the main cause of ionic imbalance because $\mathrm{Na}^{+}$is the main toxic inorganic ion in saline conditions $[59,60]$. With the increase of saline and alkaline toxicity, plants accumulate $\mathrm{Na}^{+}$ions, thereby inhibiting the absorption of $\mathrm{K}^{+}$ions. Plant species have a $\mathrm{Na}^{+} / \mathrm{H}^{+}$ antiporter that is involved in the exclusion of $\mathrm{Na}^{+}$ions and allow $\mathrm{K}^{+}$ions to enter the cell. Nonselective cation channels and high-affinity $\mathrm{K}^{+}$transporters play an important role in the excessive accumulation of intracellular $\mathrm{Na}^{+}$ions, and $\mathrm{Na}^{+}$enters the cell through these transporters and channels [61]. Due to low external proton concentration, salinity and alkalinity reduce the exchange capacity of the $\mathrm{Na}^{+} / \mathrm{K}^{+}$antiporters, which leads to a reduction in $\mathrm{Na}^{+}$exclusion, which, in turn, results in the higher accumulation of $\mathrm{Na}^{+}$ ions in the cells $[61,62]$. Therefore, reducing $\mathrm{Na}^{+}$ion exclusion might be the reason for the increase of $\mathrm{Na}^{+}$ions in the shoots of both maize hybrids. Under alkalinity stress, osmotic stress is not the cause of the increase of $\mathrm{Na}^{+}$ions in the cells, while high $\mathrm{pH}$ is the cause of the toxicity of specific ions [28]. The high $\mathrm{pH}$ value caused by alkalinity also reduces the ability of roots to absorb $\mathrm{Na}^{+}$and $\mathrm{K}^{+}$ions and disturbs the balance between $\mathrm{Na}^{+}$and $\mathrm{K}^{+}$ions $[9,63]$. Under the influence of alkalinity, the disturbance of ionic balance sharply reduces the $\mathrm{K}^{+}$ions in plant shoots [28].

The excessive accumulation of ROS caused by salinity and alkalinity enhances oxidative damage in plants. Reactive oxygen species such as $\mathrm{H}_{2} \mathrm{O}_{2}$ have a significant role in injuries caused by salt and alkali stresses. In this study, salt-alkalization significantly increased the $\mathrm{H}_{2} \mathrm{O}_{2}$ content in both maize hybrids, but this increase was greater under alkaline stress (Figure 5). Soil alkalinity causes acid-base disturbance in cells, and $\mathrm{H}_{2} \mathrm{O}_{2}$ is produced due to high $\mathrm{pH}$ [34].

Membrane damage is measured by MDA content, which is the decomposed product of polyunsaturated fatty acid hydroperoxides. As a result of lipid peroxidation, MDA content accumulates in the cells. Compared with tolerant varieties, sensitive plants accumulate more MDA content; therefore, it is used to measure plant tolerance [64,65]. In this study, an increase in MDA content was observed in both maize hybrids, but hybrid FH-1231 accumulated more MDA content than DK-6714 (Figure 5). Membrane damage is the primary effect of salt stress [66]. The injurious effects of neutral and alkaline salts on the membrane structure increase with the increase of salt concentration [20]. Specific ion toxicity leads to the accumulation of high MDA content due to membrane damage. During alkaline stress, excess $\mathrm{Na}^{+}$ions participate in the production of ROS by acting as signal molecules in the signal transduction pathway. Excessive production of ROS under salt stress can cause cell toxicity and cell damage, leading to cell death [56].

In order to maintain the balance between cell redox and detoxification of ROS, several enzymatic and nonenzymatic antioxidants play key roles under abiotic stresses. Tolerant varieties produce large amounts of antioxidants to deal with oxidative stress [67]. The 
results of the present study show that salinity and alkalinity conditions significantly regulated the activities of SOD, CAT, POD, and APX, as well as the expression levels of different antioxidant genes (Figures 6 and 7). Superoxide dismutase is an enzyme that decomposes superoxide radicals $\left(\mathrm{O}_{2}^{-}\right)$into $\mathrm{H}_{2} \mathrm{O}_{2}$. In order to overcome ROS, SOD is at the front line. They are classified according to their position in the cell and metal cofactors (such as $\mathrm{Cu} / \mathrm{Zn}, \mathrm{Fe}, \mathrm{Mn}$, and $\mathrm{Ni}$ ). In plant development, environmental and tissue-specific signals are involved in the regulation of SOD [68-70]. After SOD dismutation of $\mathrm{O}_{2}{ }^{-}$to $\mathrm{H}_{2} \mathrm{O}_{2}$, further dismutation of $\mathrm{H}_{2} \mathrm{O}_{2}$ takes place by CAT, and CAT is abundantly localized in peroxisomes. It has been found that salt stress increases CAT levels in pearl millet at reproductive and vegetative stages [71]. POD decomposition of $\mathrm{H}_{2} \mathrm{O}_{2}$ in chloroplasts is produced by SOD dismutation of $\mathrm{O}_{2}{ }^{-}$[72]. APX is present in mitochondria, chloroplast, cytosol, and peroxisomes. APX is a member of Class-I heme peroxidase and exists in the protist kingdom [73,74], red algae [75], and higher plants [76,77]. By using ascorbate as an electron donor, it participates in the catalysis of $\mathrm{H}_{2} \mathrm{O}_{2}$ to $\mathrm{H}_{2} \mathrm{O}$ [78,79]. El-Esawi et al. [80] indicated that salinity stress induced the expression levels of antioxidant genes (APX, $C A T, S O D$ ) in maize plants compared to control. Furthermore, Lin and $\mathrm{Pu}$ [81] revealed that salt-tolerant varieties have higher APX levels than salt-sensitive ones, which are in agreement with the results recorded in the current study.

\section{Conclusions}

Both salinity and alkalinity stresses reduced the biomass and growth of both maize hybrids, disrupted the ionic balance, increased the lipid peroxidation rate (MDA content) and $\mathrm{H}_{2} \mathrm{O}_{2}$ concentration, enhanced the activities of antioxidant enzymes (SOD, CAT, POD, and APX), and triggered the expression levels of antioxidant genes. For all studied traits, the negative effects of alkalinity stress were more severe than salinity. Under saline and alkaline stress conditions, DK-6714 performed better than FH-1231 and showed less reduction in growth and biomass. The greater performance of DK-6714 was associated with the higher activity of antioxidant enzymes, the maintenance of photosynthetic pigments, and the ionic balance under stress conditions.

Author Contributions: Conceptualization, investigation and methodology, A.F., S.H. (Saddam Hussain), B.A., S.H. (Sadam Hussain), U.Z., and M.A.E.-E.; formal analysis, validation, and data curation, M.A.E.-E., S.H. (Saddam Hussain), U.A., and Z.A.; data analysis, M.A.E.-E., S.H. (Sadam Hussain), U.A., Z.A., S.A.A.-R., and F.O.A.; resources and visualization, S.H. (Saddam Hussain), C.H., and M.A.E.-E.; writing—original draft, A.F., S.H. (Sadam Hussain), U.A., Z.A., and M.A.E.-E.; writing-review and editing, S.H. (Saddam Hussain), M.A.E.-E., B.A., S.A.A.-R., F.O.A., and C.H. Moreover, M.A.E.-E. and S.H. (Saddam Hussain) contributed to the molecular gene expression analysis. All authors have read and agreed to the published version of the manuscript.

Funding: This research received no external funding.

Institutional Review Board Statement: Not applicable.

Informed Consent Statement: Not applicable.

Data Availability Statement: All the data supporting the findings of this study are included in this article.

Conflicts of Interest: The authors declare no conflict of interest.

\section{References}

1. Honarjoo, N.; Mojiri, A.; Jalalian, A.; Karimzadeh, H.R. The effects of salinity and alkalinity of soil on growth of Haloxylon sp. In Proceedings of the 2010 International Conference on Chemistry and Chemical Engineering, Segzi, Iran, 1-3 Augest 2010; pp. 285-288.

2. Vysotskaya, L.; Hedley, P.E.; Sharipova, G.; Veselov, D.; Kudoyarova, G.; Morris, J.; Jones, H.G. Effect of salinity on water relations of wild barley plants differing in salt tolerance. AoB Plants 2010. [CrossRef] 
3. Dass, S.; Singh, I.; Chikkappa, G.; Parihar, C.; Kaul, J.; Singode, A.; Manivannan, A.; Singh, D. Abiotic stresses in Maize: Some issues and solutions. Dir. Maize Res. Indian Counc. Agric. Res. Pusa Campus New Delhi 2010, 110012. Available online: https://www.researchgate.net/profile/Jyoti_Kaul/publication/290908407_Abiotic_Stresses_in_Maize_Some_Issues_ and_Solutions/links/569c8a8208aea14769547d65.pdf (accessed on 27 April 2021).

4. Pakistan, M.O.F.G.O. Pakistan Economic Survey 2016-2017. 2017. Available online: http://www.finance.gov.pk/survey/ chapters_17/02-agriculture.pdf (accessed on 27 April 2021).

5. Gong, F.; Yang, L.; Tai, F.; Hu, X.; Wang, W. “Omics” of maize stress response for sustainable food production: Opportunities and challenges. Omics A J. Integr. Biol. 2014, 18, 714-732. [CrossRef] [PubMed]

6. Ahuja, I.; de Vos, R.C.; Bones, A.M.; Hall, R.D. Plant molecular stress responses face climate change. Trends Plant Sci. 2010, 15, 664-674. [CrossRef]

7. Carpici, E.B.; Celik, N.; Bayram, G. The effects of salt stress on the growth, biochemical parameter and mineral element content of some maize (Zea mays L.) cultivars. Afr. J. Biotechnol. 2010, 9, 6937-6942.

8. Hu, X.; Zhang, Y.; Shi, Y.; Zhang, Z.; Zou, Z.; Zhang, H.; Zhao, J. Effect of exogenous spermidine on polyamine content and metabolism in tomato exposed to salinity-alkalinity mixed stress. Plant Physiol. Biochem. 2012, 57, 200-209. [CrossRef]

9. Shi, D.; Wang, D. Effects of various salt-alkaline mixed stresses on Aneurolepidium chinense (Trin.) Kitag. Plant Soil 2005, 271, 15-26. [CrossRef]

10. Rao, P.S.; Mishra, B.; Gupta, S.; Rathore, A. Reproductive stage tolerance to salinity and alkalinity stresses in rice genotypes. Plant Breed. 2008, 127, 256-261. [CrossRef]

11. Yan, X.; Tan, K. Screening rice varieties for SALT tolerance in the greenhouse. IRRN 1991, 16, 16-17.

12. Alam, S.; Ansari, R.; Khan, M. Saline Agriculture and Pakistan. Industry and Economy. Pak. Load. Bus. Mag. Last 2000, 25. Available online: http:/ / www.pakistaneconomist.com (accessed on 27 April 2021).

13. Niaz, A.; Ranjha, A.; Rahmatullah, A.H.; Waqas, M. Boron status of soils as affected by different soil characteristics-pH, CaCO3, organic matter and clay contents. Pak. J. Agric. Sci. 2007, 44, 428-435.

14. Azooz, M.; Shaddad, M.; Abdel-Latef, A. Leaf growth and $\mathrm{K}+/ \mathrm{Na}+$ ratio as an indication of the salt tolerance of three sorghum cultivars grown under salinity stress and IAA treatment. Acta Agron. Hung. 2004, 52, 287-296. [CrossRef]

15. Sultana, N.; Ikeda, T.; Kashem, M. Effect of seawater on photosynthesis and dry matter accumulation in developing rice grains. Photosynthetica 2002, 40, 115-119. [CrossRef]

16. Rengasamy, P. Soil processes affecting crop production in salt-affected soils. Funct. Plant Biol. 2010, 37, 613-620. [CrossRef]

17. Saslis-Lagoudakis, C.H.; Hua, X.; Bui, E.; Moray, C.; Bromham, L. Predicting species' tolerance to salinity and alkalinity using distribution data and geochemical modelling: A case study using Australian grasses. Ann. Bot. 2015, 115, 343-351. [CrossRef] [PubMed]

18. Shi, D. Effects of $\mathrm{NaCl}$ and $\mathrm{Na}_{2} \mathrm{CO}_{3}$ on growth of Puccinellia tenuiflora and on present state of mineral elements in nutrient solution. Acta Pratacu. Sin. 1997, 6, 51-61.

19. Yang, C.; Wang, P.; Li, C.; Shi, D.; Wang, D. Comparison of effects of salt and alkali stresses on the growth and photosynthesis of wheat. Photosynthetica 2008, 46, 107-114. [CrossRef]

20. Zhanwu, G.; Jiayu, H.; Chunsheng, M.; Jixiang, L.; Xiaoyu, L.; Lidong, L.; Shengnan, S. Effects of saline and alkaline stresses on growth and physiological changes in oat (Avena sativa L.) seedlings. Not. Bot. Horti Agrobot. Cluj Napoca 2014, 42, 357-362.

21. Guo, R.; Shi, L.; Yan, C.; Zhong, X.; Gu, F.; Liu, Q.; Xia, X.; Li, H. Ionomic and metabolic responses to neutral salt or alkaline salt stresses in maize (Zea mays L.) seedlings. BMC Plant Biol. 2017, 17, 41. [CrossRef]

22. Pardo, J.M.; Quintero, F.J. Plants and sodium ions: Keeping company with the enemy. Genome Biol. 2002, 3, 1-4. [CrossRef] [PubMed]

23. Lu, S.; Zhang, S.; Xu, X.; Korpelainen, H.; Li, C. Effect of increased alkalinity on $\mathrm{Na}^{+}$and $\mathrm{K}^{+}$contents, lipid peroxidation and antioxidative enzymes in two populations of Populus cathayana. Biol. Plant 2009, 53, 597. [CrossRef]

24. Bazzaz, M.M.; Hossain, M.A. Plant water relations and proline accumulations in soybean under salt and water stress environment. J. Plant Sci. 2015, 3, 272-278.

25. Cramer, G.R.; Nowak, R.S. Supplemental manganese improves the relative growth, net assimilation and photosynthetic rates of salt-stressed barley. Physiol. Plant 1992, 84, 600-605. [CrossRef]

26. Sali, A.; Rusinovci, I.; Fetahu, S.; Gashi, B.; Simeonovska, E.; Rozman, L. The effect of salt stress on the germination of maize (Zea mays L.) seeds and photosynthetic pigments. Acta Agric. Slov. 2015, 105, 85-94.

27. Nishiuchi, S.; Fujihara, K.; Liu, S.; Takano, T. Analysis of expressed sequence tags from a NaHCO3-treated alkali-tolerant plant, Chloris virgata. Plant Physiol. Biochem. 2010, 48, 247-255. [CrossRef]

28. Zhang, J.-T.; Mu, C.-S. Effects of saline and alkaline stresses on the germination, growth, photosynthesis, ionic balance and anti-oxidant system in an alkali-tolerant leguminous forage Lathyrus quinquenervius. Soil Sci. Plant Nutr. 2009, 55, 685-697. [CrossRef]

29. Trchounian, A.; Petrosyan, M.; Sahakyan, N. Plant cell redox homeostasis and reactive oxygen species. In Redox State as a Central Regulator of Plant-Cell Stress Responses; Springer: Cham, Switzerland, 2016; pp. 25-50. [CrossRef]

30. Mittler, R. Oxidative stress, antioxidants and stress tolerance. Trends Plant Sci. 2002, 7, 405-410. [CrossRef]

31. Neill, S.; Desikan, R.; Hancock, J. Hydrogen peroxide signalling. Curr. Opin. Plant Biol. 2002, 5, 388-395. [CrossRef] 
32. Das, K.; Roychoudhury, A. Reactive oxygen species (ROS) and response of antioxidants as ROS-scavengers during environmental stress in plants. Front. Environ. Sci. 2014, 2, 53. [CrossRef]

33. Van Breusegem, F.; Vranová, E.; Dat, J.F.; Inzé, D. The role of active oxygen species in plant signal transduction. Plant Sci. 2001, 161, 405-414. [CrossRef]

34. Gill, S.S.; Tuteja, N. Reactive oxygen species and antioxidant machinery in abiotic stress tolerance in crop plants. Plant Physiol. Biochem. 2010, 48, 909-930. [CrossRef]

35. Xu, Y.; Kim, S.O.; Li, Y.; Han, J. Autophagy contributes to caspase-independent macrophage cell death. J. Biol. Chem. 2006, 281, 19179-19187. [CrossRef]

36. Williams, V.; Twine, S. Flame photometric method for sodium, potassium and calcium. Mod. Methods Plant Anal. $1960,5,3-5$.

37. Velikova, V.; Yordanov, I.; Edreva, A. Oxidative stress and some antioxidant systems in acid rain-treated bean plants: Protective role of exogenous polyamines. Plant Sci. 2000, 151, 59-66. [CrossRef]

38. Heath, R.L.; Packer, L. Photoperoxidation in isolated chloroplasts: I. Kinetics and stoichiometry of fatty acid peroxidation. Arch. Biochem. Biophys. 1968, 125, 189-198. [CrossRef]

39. Chance, B.; Maehly, A. Assay of catalases and peroxidases. Methods Enzym. 1955, 2, 764-775.

40. Dhindsa, R.S.; Plumb-Dhindsa, P.; Thorpe, T.A. Leaf senescence: Correlated with increased levels of membrane permeability and lipid peroxidation, and decreased levels of superoxide dismutase and catalase. J. Exp. Bot. 1981, 32, 93-101. [CrossRef]

41. Nakano, Y.; Asada, K. Hydrogen peroxide is scavenged by ascorbate-specific peroxidase in spinach chloroplasts. Plant Cell Physiol. 1981, 22, 867-880.

42. Vwioko, E.; Adinkwu, O.; El-Esawi, M.A. Comparative Physiological, Biochemical and Genetic Responses to Prolonged Waterlogging Stress in Okra and Maize Given Exogenous Ethylene Priming. Front. Physiol. 2017, 8, 632. [CrossRef]

43. Neta, I.C.S.; Von Pinho, É.V.D.R.; de Abreu, V.M.; dos Santos, H.O.; Vilela, D.R.; Von Pinho, R.G.; de Carvalho, M.L.M. Enzyme activities and gene expression in dry maize seeds and seeds submitted to low germination temperature. Afr. J. Agric. Res. 2016, 11, 3097-3103.

44. Huang, H.; Lv, L.; Wang, D.; Guo, B.; Lv, J.; Luo, L.; Wen, B.; Kang, Y. Biochemical and molecular responses of maize (Zea mays L.) to 1, 2-dibromo-4- (1, 2 dibromoethyl) cyclohexane (TBECH) diastereomers: Oxidative stress, DNA damage, antioxidant enzyme gene expression and diversity of root exudates. Sci. Total Environ. 2021, 753, 141872. [CrossRef]

45. Livak, K.J.; Schmittgen, T.D. Analysis of relative gene expression data using real-time quantitative PCR and the 2 (-Delta Delta C (T)) method. Methods 2001, 25, 402-408. [CrossRef] [PubMed]

46. Lv, B.S.; Li, X.W.; Ma, H.Y.; Sun, Y.; Wei, L.X.; Jiang, C.J.; Liang, Z.W. Differences in Growth and Physiology of Rice in Response to Different Saline-Alkaline Stress Factors. Agron. J. 2013, 105, 1119-1128. [CrossRef]

47. Guo, M.; Wang, R.; Wang, J.; Hua, K.; Wang, Y.; Liu, X.; Yao, S. ALT1, a Snf2 family chromatin remodeling ATPase, negatively regulates alkaline tolerance through enhanced defense against oxidative stress in rice. PLoS ONE 2014, 9, e112515. [CrossRef]

48. Wei, L.-X.; Lv, B.-S.; Wang, M.-M.; Ma, H.-Y.; Yang, H.-Y.; Liu, X.-L.; Jiang, C.-J.; Liang, Z.-W. Priming effect of abscisic acid on alkaline stress tolerance in rice (Oryza sativa L.) seedlings. Plant Physiol. Biochem. 2015, 90, 50-57. [CrossRef] [PubMed]

49. AbdElgawad, H.; Zinta, G.; Hegab, M.M.; Pandey, R.; Asard, H.; Abuelsoud, W. High salinity induces different oxidative stress and antioxidant responses in maize seedlings organs. Front. Plant Sci. 2016, 7, 276. [CrossRef]

50. Wang, L.; Seki, K.; Miyazaki, T.; Ishihama, Y. The causes of soil alkalinization in the Songnen Plain of Northeast China. Paddy Water Environ. 2009, 7, 259-270. [CrossRef]

51. Amini, S.; Ghadiri, H.; Chen, C.; Marschner, P. Salt-affected soils, reclamation, carbon dynamics, and biochar: A review. J. Soils Sediments 2016, 16, 939-953. [CrossRef]

52. Taiz, L.; Zeiger, E. Plant Physiology, 4th ed.; Sinauer Associates, Inc., Publishers: Sunderland, MA, USA, 2006 ; p. 764.

53. Roychoudhury, A.; Basu, S. Overexpression of an abiotic-stress inducible plant protein in the bacteria Escherichia coli. Afr. J. Biotechnol. 2008, 7, 3231-3234. Available online: https:/ /www.ajol.info/index.php/ajb/article/view/59263 (accessed on 27 April 2021).

54. Rao, G.; Rao, G. Pigment composition and chlorophyllase activity in pigeon pea (Cajanus indicus Spreng) and Gingelley (Sesamum indicum L.) under $\mathrm{NaCl}$ salinity (1981). Indian J. Exp. Biol. 2013, 19, 768-770.

55. Noreen, Z.; Ashraf, M. Assessment of variation in antioxidative defense system in salt-treated pea (Pisum sativum) cultivars and its putative use as salinity tolerance markers. J. Plant Physiol. 2009, 166, 1764-1774. [CrossRef]

56. Kariola, T.; Brader, G.; Li, J.; Palva, E.T. Chlorophyllase 1, a damage control enzyme, affects the balance between defense pathways in plants. Plant Cell 2005, 17, 282-294. [CrossRef]

57. Latef, A.A.H.A.; Chaoxing, H. Effect of arbuscular mycorrhizal fungi on growth, mineral nutrition, antioxidant enzymes activity and fruit yield of tomato grown under salinity stress. Sci. Hortic. 2011, 127, 228-233. [CrossRef]

58. Abdel Latef, A.; Abu Alhmad, M.; Sallam, M. Comparative study of the physiological response of two wheat cultivars to salinity stress. Assiut Univ. J. Bot. 2014, 43, 55-69.

59. James, R.A.; Davenport, R.J.; Munns, R. Physiological characterization of two genes for Na+ exclusion in durum wheat, Nax1 and Nax2. Plant Physiol. 2006, 142, 1537-1547. [CrossRef] [PubMed]

60. Chen, S.; Xing, J.; Lan, H. Comparative effects of neutral salt and alkaline salt stress on seed germination, early seedling growth and physiological response of a halophyte species Chenopodium glaucum. Afr. J. Biotechnol. 2012, 11, 9572-9581.

61. Zhu, J.-K. Regulation of ion homeostasis under salt stress. Curr. Opin. Plant Biol. 2003, 6, 441-445. [CrossRef] 
62. Munns, R.; Tester, M. Mechanisms of salinity tolerance. Annu. Rev. Plant Biol. 2008, 59, 651-681. [CrossRef]

63. Shi, D.; Sheng, Y. Effect of various salt-alkaline mixed stress conditions on sunflower seedlings and analysis of their stress factors. Environ. Exp. Bot. 2005, 54, 8-21. [CrossRef]

64. Mandhania, S.; Madan, S.; Sawhney, V. Antioxidant defense mechanism under salt stress in wheat seedlings. Biol. Plant 2006, 50, 227-231. [CrossRef]

65. Ahmad, P.; Kumar, A.; Ashraf, M.; Akram, N.A. Salt-induced changes in photosynthetic activity and oxidative defense system of three cultivars of mustard (Brassica juncea L.). Afr. J. Biotechnol. 2012, 11, 2694-2703.

66. Ashraf, M.; Athar, H.; Harris, P.; Kwon, T. Some prospective strategies for improving crop salt tolerance. Adv. Agron. 2008, 97, 45-110.

67. Caverzan, A.; Casassola, A.; Brammer, S.P. Antioxidant responses of wheat plants under stress. Genet. Mol. Biol. 2016, 39, 1-6. [CrossRef] [PubMed]

68. Scandalios, J.G. Oxidative Stress and the Molecular Biology of Antioxidant Defenses; Cold Spring Harbor Laboratory Press: New York, NY, USA, 1997.

69. Scandalios, J. Oxidative stress: Molecular perception and transduction of signals triggering antioxidant gene defenses. Braz. J. Med. Biol. Res. 2005, 38, 995-1014. [CrossRef]

70. Menezes-Benavente, L.; Teixeira, F.K.; Kamei, C.L.A.; Margis-Pinheiro, M. Salt stress induces altered expression of genes encoding antioxidant enzymes in seedlings of a Brazilian indica rice (Oryza sativa L.). Plant Sci. 2004, 166, 323-331. [CrossRef]

71. Heidari, M.; Jamshidi, P. Effects of salinity and potassium application on antioxidant enzyme activities and physiological parameters in pearl millet. Agric. Sci. China 2011, 10, 228-237. [CrossRef]

72. Bor, M.; Özdemir, F.; Türkan, I. The effect of salt stress on lipid peroxidation and antioxidants in leaves of sugar beet Beta vulgaris L. and wild beet Beta maritima L. Plant Sci. 2003, 164, 77-84. [CrossRef]

73. Shigeoka, S.; Nakano, Y.; Kitaoka, S. Metabolism of hydrogen peroxide in Euglena gracilis Z by L-ascorbic acid peroxidase. Biochem. J. 1980, 186, 377-380. [CrossRef] [PubMed]

74. Wilkinson, S.R.; Obado, S.O.; Mauricio, I.L.; Kelly, J.M. Trypanosoma cruzi expresses a plant-like ascorbate-dependent hemoperoxidase localized to the endoplasmic reticulum. Proc. Natl. Acad. Sci. USA 2002, 99, 13453-13458. [CrossRef]

75. Sano, S.; Ueda, M.; Kitajima, S.; Takeda, T.; Shigeoka, S.; Kurano, N.; Miyachi, S.; Miyake, C.; Yokota, A. Characterization of ascorbate peroxidases from unicellular red alga Galdieria partita. Plant Cell Physiol. 2001, 42, 433-440. [CrossRef]

76. Takeda, T.; Yoshimura, K.; Ishikawa, T.; Shigeoka, S. Purification and characterization of ascorbate peroxidase in Chlorella vulgaris. Biochimie 1998, 80, 295-301. [CrossRef]

77. Takeda, T.; Yoshimura, K.; Yoshii, M.; Kanahoshi, H.; Miyasaka, H.; Shigeoka, S. Molecular characterization and physiological role of ascorbate peroxidase from halotolerant Chlamydomonas sp. W80 strain. Arch. Biochem. Biophys. 2000, 376, 82-90. [CrossRef]

78. Caverzan, A.; Passaia, G.; Rosa, S.B.; Ribeiro, C.W.; Lazzarotto, F.; Margis-Pinheiro, M. Plant responses to stresses: Role of ascorbate peroxidase in the antioxidant protection. Genet. Mol. Biol. 2012, 35, 1011-1019. [CrossRef]

79. Caverzan, A.; Bonifacio, A.; Carvalho, F.E.; Andrade, C.M.; Passaia, G.; Schünemann, M.; dos Santos Maraschin, F.; Martins, M.O.; Teixeira, F.K.; Rauber, R. The knockdown of chloroplastic ascorbate peroxidases reveals its regulatory role in the photosynthesis and protection under photo-oxidative stress in rice. Plant Sci. 2014, 214, 74-87. [CrossRef] [PubMed]

80. El-Esawi, M.A.; Alaraidh, I.A.; Alsahli, A.A.; Alzahrani, S.M.; Ali, H.M.; Alayafi, A.A.; Ahmad, M. Serratia liquefaciens KM4 Improves Salt Stress Tolerance in Maize by Regulating Redox Potential, Ion Homeostasis, Leaf Gas Exchange and Stress-Related Gene Expression. Int. J. Mol. Sci. 2018, 19, 3310. [CrossRef] [PubMed]

81. Lin, K.; Pu, S. Tissue-and genotype-specific ascorbate peroxidase expression in sweet potato in response to salt stress. Biol. Plant 2010, 54, 664-670. [CrossRef] 